\title{
Results on complex treatment of patients with glial tumors of brain with local chemotherapy
}

\author{
L. R. Harutyunyan \\ National Center of Oncology named after V. A. Fanarjyan, MH of Republic of Armenia \\ 76, Fanarjyan Str., Yerevan, Republic of Armenia, 0052 \\ levon_neuro@yahoo.com
}

\begin{abstract}
Aim. For the purpose of local chemotherapy in patients with malignant brain tumors after partial or total removal of tumors we used biodegradable film with methotrexate. The film, due to its properties, is firmly attached to the wound surface. With its composition of chemotherapeutic agents over specified time, the dosed film immediately affects diseased tissue, playing the role of a local chemotherapy depo. Methods. Results of treatment of 74 patients with low differentiated gliomas of the brain, which have undergone a comprehensive treatment that includes surgical removal of tumor and implantation of methotrexate depo in the wall of postoperative cerebral injury followed by radiotherapy in the pig on a bed of the tumor removed. Results. A retrospective analysis of the results of complex treatment of patients with glial brain tumors with local chemotherapy showed a significant increase in disease-free period in patients who have undergone, consistently, surgery, chemotherapy and adjuvant local radiation therapy. Conclusions. Our research has shown that the use of local chemotherapy greatly improves the results of treatment of patients not only for total removal of intracerebral tumors, but also for subtotal removal, as well as in patients with prolonged tumor growth, when there is no possibility of radiation treatment.
\end{abstract}

Keywords: glial tumors, local chemotherapy, methotrexate, polymeric film.

Introduction. Intracerebral or glial tumors account for $50 \%$ of all tumors of the central nervous system. Despite diagnostics improvement, a mortality of patients with intracerebral tumors remains high, and results of treatment are unsatisfactory. A role of adjuvant chemotherapy up to date has not been fully clarified.

We attempted to solve the problem of developing the most optimal way to deliver chemotherapeutic agents to partially resected tumor, or to the areas of previously removed brain tumor. Our studies on experimental animals indicated the preferred activation mechanisms of apoptosis in the drugs implanted films with methotrexate, compared to the drugs with a depot effect of cisplatin.

(c) Institute of Molecular Biology and Genetics, NAS of Ukraine, 2011
Low grade glioma (LGG) is a group of malignant brain tumors of neuroectodermal origin. According to the WHO classification, they include: anaplastic glioma (anaplastic astrocytoma, oligodendrogliomas and oligoastrocytomas) and glioblastoma multiforme.

Treatment of patients with low grade gliomas remains today one of the most pressing problems of neurosurgery and oncology. Despite using practically entire arsenal of anticancer therapies and surgical techniques, the average life of patients with LGG usually does not exceed 12 months.

From biological viewpoint on tumoral growth, LGG represents the local process that affords a possibility of wide application of local methods of anticancer therapy at this disease. The local chemotherapy is the most perspective in this respect. 
The studied and control groups

\begin{tabular}{|c|c|c|c|c|}
\hline \multirow{2}{*}{$\begin{array}{l}\text { Histological structure of } \\
\text { tumor }\end{array}$} & \multirow{2}{*}{ All patients } & \multicolumn{3}{|c|}{ Disease-free period } \\
\hline & & Less than 6 months & Less than 1 year & More than 1 year \\
\hline \multicolumn{5}{|c|}{ The studied group } \\
\hline $\begin{array}{l}\text { Anaplastic } \\
\text { astrocytoma }\end{array}$ & 30 & 6 & 7 & 17 \\
\hline $\begin{array}{l}\text { Anaplastic } \\
\text { oligoastrocytomas }\end{array}$ & 14 & 1 & 2 & 11 \\
\hline $\begin{array}{l}\text { Anaplastic } \\
\text { oligodendrogliomas }\end{array}$ & 9 & - & - & 9 \\
\hline Glioblastoma & 21 & 1 & 2 & 18 \\
\hline Total & 74 & $8(10.8 \%)$ & $11(14.86 \%)$ & $55(74.3 \%)$ \\
\hline \multicolumn{5}{|c|}{ The control group } \\
\hline $\begin{array}{l}\text { Anaplastic } \\
\text { astrocytoma }\end{array}$ & 36 & 12 & 17 & 7 \\
\hline $\begin{array}{l}\text { Anaplastic } \\
\text { oligoastrocytomas }\end{array}$ & 14 & 4 & 8 & 2 \\
\hline $\begin{array}{l}\text { Anaplastic } \\
\text { oligodendrogliomas }\end{array}$ & 10 & 2 & 4 & 4 \\
\hline Glioblastoma & 20 & 6 & 10 & 4 \\
\hline Total & 80 & $24(30 \%)$ & $39(48.7 \%)$ & $17(21.3 \%)$ \\
\hline
\end{tabular}

In both domestic and foreign literature there are numerous publications regarding clinical experience with solutions of various anticancer drugs for local chemotherapy, but the results were not very comforting. In recent years, some investigators attempted to use the brain-polymer formulations of cytotoxic drugs deposited in resorbable polymers for local chemotherapy of non-differentiated gliomas.

Materials and methods. For local chemotherapy of patients with glial brain tumors after partial or total removal of tumors we used self-resolving film with methotrexate. One option for the localization of anticancer drugs may be their deposition in the polymer matrix (biodegradable), and the tool itself realized in the form of a multilayer polymeric film, affixed to the affected area.

Successful application of a polymer adhesive selfresolving film of «diplen» in medical practice allowed us to use the latter as a basis for creating anticancer drug depot with the cytostatic methotrexate.
The films, due to their properties, are firmly attached to the wound surface. With the composition of chemotherapeutic agents over a specified time, the films being resolvable and dosed, directly affect the diseased tissue, playing the role of a depot chemotherapy.

74 patients with the brain LGG had undergone a comprehensive treatment that included surgical removal of the tumor within the intact brain tissue, or after subtotal removal, with implantation in the wall of the postoperative brain injury depot methotrexate followed by radiotherapy in the total focal dose in resected tumor bed of $60 \mathrm{~Gy}$.

80 patients in the control group had undergone a standard combination therapy consisting of similar surgery and radiation therapy on ODS in the removed tumor region (60 Gy).

For histological classification the tumors were assigned to the following groups: anaplastic astrocytoma - 30; anaplastic oligoastrocytomas - 14; anaplastic oligodendrogliomas -9 ; glioblastoma -21 . The pa- 
tients' age from 10 to 78 years. The median age was 50 years. There were 38 men, 36 women.

In the group studied 48 patients received complex treatment: surgery with total or subtotal resection of tumor and implantation of the polymer film with methotrexate for the local chemotherapy and adjuvant radiation therapy.

The remaining 26 patients underwent only surgery with implantation of the polymer film with methotrexate, and postoperative radiation therapy was performed. Of the 74 patients studied, 23 with continuing growth of the previously removed malignant brain tumor were operated on. This group consisted mostly of the patients who did not receive postoperative radiation therapy, as they completed the full course of radiation treatment after the first operation. The remaining 3 patients, for various reasons, refused radiotherapy.

An assessment of the overall condition of the patients on admission was made on a scale of Karnoffskiy and ranged from $40 \%$ to $80 \%$.

As accompanying diseases 5 patients had diabetes, 4 -hypertension, 4 - varicose veins of the lower extremities, 2 - hepatitis C, 1 - calculous cholecystitis, and 1 - syphilis.

The operations were performed under general anesthesia. Of 74 patients in 61 the tumor was removed within a macroscopically visible healthy tissue, in 13 subtotally.

Results and discussion. Our study showed that the patients with glial structures of the brain consist $50 \%$ of the total number of neuro-oncology patients. The most aggressive in terms of recurrence of the tumor is anaplastic astrocytoma.

A comparative analysis of relapse-free period between the studied and control groups is presented in the Table.

A retrospective analysis of the results of complex treatment of patients with glial brain tumors with local chemotherapy showed a significant increase in diseasefree period in the patients who have undergone, consistently, surgery, chemotherapy and adjuvant local radiation therapy.

Our research has shown that the use of local chemotherapy greatly improves the results of treatment of patients not only for total removal of intracerebral tumors, but also for subtotal removal, as well as in pati- ents with prolonged tumor growth, when there is no possibility of radiation treatment.

Thus, we examined the results of complex treatment of patients with glial brain tumors using the method of local chemotherapy. Given these results, we believe further research is very promising in this regard.

\section{Л. Р. Арутюнян}

Результати комплексного лікування хворих гліальними пухлинами головного мозку із застосуванням локальної хіміотерапії

Резюме

Мета. Для проведення локальної хіміотерапї у хворих злоякісними пухлинами головного мозку після часткового або тотального видалення пухлин нами використано плівку з метотрексатом, здатну саморозсмоктуватися. Завдяки своїм властивостям плівка міцно приклеюється до поверхні рани. Маючи у своєму складі хіміопрепарат, протягом заданого часу плівка, розсмоктуючися, безпосередньо і дозовано впливає на пошкоджені тканини, виконуючи роль своєрідного депо хіміопрепарату. Методи. Проаналізовано результати комплексного лікування 74 хворих низькодиференційованими гліомами головного мозку, яким хірургічним шляхом видалено пухлину з імплантацією на стінки післяопераційної мозкової рани депонованої форми метотрексату, з наступною променевою терапією в СОД на місиі видаленої пухлини. Результати. Ретроспективний аналіз результатів комплексного лікування хворих гліальними пухлинами головного мозку із застосуванням локальної хіміотерапії виявив значне збільшення безрециидивного періоду у хворих, яким послідовно здійснили хірургічне втручання, локальну хіміотерапію та ад 'ювантний курс променевої терапії. Висновки. Намі дослідження показали, щяо використання локальної хіміотерапії набагато покрашує результати комплексного лікування хворих не лише за тотального, але й субтотального видалення внутрішньомозкової пухлини, а також у хворих з подовженим ростом пухлини, коли немає можливості променевого лікування.

Ключові слова: гліальні пухлини, локальна хіміотерапія, метотрексат, полімерна плівка.

\section{Л. Р. Арутюнян}

Результаты комплексного лечения больных глиальными опухолями головного мозга с применением локальной химиотерапии

Резюме

Цель. Для проведения локальной химиотерапии у больных злокачественными опухолями головного мозга после частичного или тотального удаления опухолей нами использована саморассасываюшаяся пленка с метотрексатом. Благодаря своим свойствам пленка прочно приклеивается к раневой поверхности. Имея в своем составе химиопрепарат, с течением заданного времени плен$\kappa a$, рассасываясь, непосредственно и дозированно влияет на пораженные ткани, играя роль своеобразного депо химиопрепарата. Методы. Проанализированы результаты комплексного лечения 74 больных низкодифференцированными глиомами головного мозга, которым было проведено хирургическое удаление опухоли с им- 
плантацией на стенки послеоперационной мозговой раны депонированной формы метотрексата, с последующей лучевой терапией в СОД на ложе удаленной опухоли. Результаты. Ретроспективный анализ результатов комплексного лечения больных глиальными опухолями головного мозга с использованием локальной химиотерапии выявил значительное увеличение безрецидивного периода у больных, подвергшигся последовательно хирургическому вмешательству, локальной химиотерапии и адъювантному курсу лучевой терапии. Выводы. Наши исследования показали, что применение локальной химиотерапии намного улучшает результаты комплексного лечения больных не только при тотальном, но и субтотальном удалении внутримозговой опухоли, а также у больных с продолженным ростом опухоли, когда нет возможности лучевого лечения.

Ключевые слова: глиальные опухоли, локальная химиотерапия, метотрексат, полимерная пленка.

\section{REFERENCES}

1. Konstantinova $M$. M. Sovremennoye sostoyaniye i perspektivy khimioterapii zlokachestvennykh opukholey golovnogo mozga // Sovremennaya Onkologiya.-2002.-4, N 3.-P. 144-149.

2. Kolosov A. E., Koshchug S. D., Mel'nikov R. A. Sovremennaya klassifikatsiya opukholey (gistologicheskaya, tsitologicheskaya, klinicheskaya).-Kishinev: Shtiintsa, 1990.-P. 152-156.
3. Romodanov A. P., Sosnov Yu. D. Method of regional and local chemotherapy in treatment of malignant tumors of the brain // Vestn. Akad. med. nauk SSSR.-1974.-29, N 11.-P. 83-86.

4. Boiardi A., Salmaggi A., Pozzi A., Broggi G., Silvani A. Interstitial chemotherapy with mitoxantrone in recurrent malignant glioma: preliminary data // J. Neurooncol.-1996.-27, N 2.-P. $157-$ 162.

5. Brem H., Ewend M. G., Piantadosi S., Greenhoot J., Burger P. C., Sisti $M$. The safety of interstitial chemotherapy with BCNUloaded polymer followed by radiation therapy in the treatment of newly diagnosed malignant gliomas: phase I trial // J. Neurooncol.-1995.-26, N 2.-P. 111-123.

6. Olivi A., Barker F., Tatter S., Bruce J., Judy K., Engelhard H., Burak E., Hilt D., Grossman S., Joy F., Piantadosi S. Toxicity and pharmacokinetics of interstitial BCNU administered via wafers: results of a phase i study in patients with recurrent malignant glioma // Abstr. of Annual Meeting of the American Society of Clinical Oncology.-1999.-P. 143a.

7. Kong Q., Kleinschmidt-Demasters B. K., Lillehei K. O. Intralesionally implanted cisplatin cures primary brain tumor in rats // J. Surg. Oncol.-1997.-64, N 4.-P. 268-273.

UDC 616-006.48:616-089.168

Received 20.07.11 